Invited Editorial

ISSN: 2162-3104 Print/ ISSN: 2166-3750 Online

Volume 8, Issue 4 (2018), pp. 1479-1482

(C) Journal of International Students

http://jistudents.org/

doi: 10.5281/zenodo.1467801

\title{
International Students in the Era of Trump and Brexit: Implications, Constructions and Trends
}

\author{
Brendan Bartram \\ University of Wolverhampton, $U K$
}

As Rose-Redwood and Rose-Redwood (2017) made plain:

We are living in troubling and uncertain times. Xenophobia is on the rise as right-wing, authoritarian nationalism has witnessed significant electoral gains and the very ideals of democratic inclusiveness and international pluralism are under direct attack. With the election of Donald Trump as President of the United States, the country with the largest share of international students globally is increasingly becoming an unwelcoming place to study abroad. (p. i)

The above authors are far from alone in making such claims (see Watt, Costa Candal, \& Quiason, 2018, for example). Across the Global North in fact, many commentators have begun to note the expansion and spread of nationalist sentiments with some concern. Outside of the US, in the immediate aftermath of the U.K. vote to leave the European Union (EU) in the June 2016 referendum, there was an alarming increase in reported incidents of hate crime targeted at non-U.K. nationals (Burnett, 2017). These varied from physical attacks on individuals to verbal abuse and cyber assaults. Commentators suggested that the vote to leave had somehow-and for some people-legitimized the open display of negative attitudes toward foreigners and cultural difference, casual xenophobia, and indeed racist behavior (Khalili, 2016). After many years of uneasy E.U. membership (Ford \& Goodwin, 2017), a decision had been taken to reject a notion of unity and cooperation with the UK's European neighbors in favor of what others have variously interpreted as a desire for independence driven by 
beliefs in cultural superiority and/or national self-sufficiency; misplaced nostalgia for a return to a mythical Great British past; or long-standing and generic "Euro-scepticism." However, we interpret the symbolic significance of Brexit - and it must be acknowledged that there are more charitable interpretations - it is difficult to read it as an endorsement of outward looking positivity towards Europe, and potentially, "outsiders" in general.

Although it should be recognized that many international students have long experienced the varied challenges of unwelcoming environments (see Lee \& Rice, 2007, for example), the developments described above constitute something of a landmark political and cultural shift with potentially significant implications and consequences for international students. Dennis (2017) likewise acknowledged this, pointing out that:

Current data reveal that colleges and universities in both Great Britain and the United States have received fewer applications from international students for the fall 2017 semester. There are several surveys and reports revealing that many international students believe both countries are not welcoming to international students. (p. 3)

As such, researchers in the social sciences now have a particularly important part to play in investigating how this troubling political and sociocultural scenario is impacting international students. The need for such research is three-fold - as always, it will have intrinsic importance in advancing our understanding of students' contemporary life-worlds - but it will be important for two further extrinsic reasons: on the one hand, because of its potential to act as a mechanism for monitoring and recording potentially unwelcome social and political effects, and on the other hand, because it can generate an evidence base that can be used as a basis for action, reflection, and awareness raising in the interests of improving social justice.

What specifically might such research focus on? Rose-Redwood and Rose-Redwood (2017, pp. ii-iii), in their powerful and persuasive call for a reappraisal of the research agenda on international students identified five key themes that represent important lines of enquiry in the current context:

- The policy environment

- The sociopolitical atmosphere

- The continuum of violence and discrimination

- The degree of student activism and resistance

- The researcher positionality effect 
They elaborate by providing a usefully detailed set of suggestions and questions worthy of research attention in relation to each theme. In addition to these, I would also suggest that research should focus on the extent to which institutions are taking steps to monitor potential discrimination and tailor appropriate support provision for international students. Furthermore, what coping strategies - and how effectively - do students employ to deal with changing demands, experiences, and needs? Clearly, the above offers a wide range of angles and avenues to pursue, all of them important in helping us both to further our understanding and generate new and nuanced insights into international students' experiences in the wake of the changing sociopolitical landscape depicted above, and the implications this has for how they are constructed, perceived, and received.

\section{REFERENCES}

Burnett, J. (2017). Racial violence and the Brexit state. Race and Class, 58(4), 8597.

Dennis, M. (2017). International student mobility and the new world disorder. Enrollment Management Support, 21(8), 3-5.

Ford, R., \& Goodwin, M. (2017). Britain after Brexit: A nation divided. Journal of Democracy, 28, 17-30.

Khalili, L. (2016, June 30). After Brexit: Reckoning with Britain's racism and xenophobia, truthout. Retrieved from http://www.truth-out.org/ opinion/item/36651-after-brexit-reckoning-with-britain-s-racism-andxenophobia

Lee, J. J., \& Rice, C. (2007). Welcome to America? International student perceptions of discrimination and neo-racism. Higher Education 53, 381409.

Rose-Redwood, C., \& Rose-Redwood, R. (2017). Rethinking the politics of the international student experience in the age of Trump. Journal of International Students, 7(3), i-ix.

Watt, S., Costa Candal, C., \& Quiason, M. (2018). Marginalization and fear? Concealed carry and campus climate in the Trump era. Women, Gender, and Families of Color, (6)1. doi:10.5406/womgenfamcol.6.1.fm

BRENDAN BARTRAM, PhD, is Reader in Education at the University of Wolverhampton, UK. He was awarded a National Teaching Fellowship by the Higher Education Academy in 2012. His research and publications cover a wide range of issues related primarily to higher education practice, pedagogy, and policy. Much of this work has involved a comparative dimension, examining such themes as international student mobility, behavior, support and motivation. Outside of higher education, his book, Attitudes to Modern Language Learning - Insights from Comparative Education, examined secondary language learning in the UK, US, 
Australia, Germany, and the Netherlands. Brendan is a member of the British Education Studies Association and was honorary secretary of British Association of International and Comparative Education. Email: b.bartram@wlv.ac.uk 